\title{
SOCIAL INEQUALITY AND HOMEOWNERSHIP FROM A COMPARATIVE PERSPECTIVE: IS THERE A RETURN OF THE WELFARE STATE?
}

Desigualdad social y propiedad de vivienda desde una perspectiva comparativa: ¿hay un regreso del estado del bienestar?

\author{
Hicham Raïq \\ Qatar University \\ hraiq@qu.edu.qa
}

Chedli Baya Chatti

Qatar University

cchatti@qu.edu.qa

\author{
Abdel-Samad M. Ali \\ Qatar University \\ abdelsamad@qu.edu.qa
}

\begin{abstract}
Esping-Andersen's typology of welfare state regimes has been one of the most influential contributions to comparative studies. The general picture of this typology has four variants: social democratic, conservative, southern European, and liberal regimes. This typology becomes controversial particularly when homeownership inequalities are considered. Our study aims to evaluate the sustainability of the welfare state regime typology with regard to reducing inequalities of homeownership. The paper uses data from the Luxembourg Income Study to analyze the changes in homeownership rates for low-income populations as compared to the entire population. We compared ten countries representing various welfare regimes from 2000 to 2013/16 to examine the variations of homeownership and social inequalities over time. The results show that the distribution of countries seems to have a negative correlation between welfare regimes (according to the Gini index) and homeownership rates. In liberal countries (except Canada) and southern European
\end{abstract}


countries, homeownership rates fell over time. In most of these countries, low-income populations experienced the highest decline in homeownership rates during the observed period.

KeYwORDs: Welfare state, homeownership, social inequality, housing, low-income class.

RESUMEN: La tipología de los regímenes del Estado de bienestar de Esping-Andersen ha sido una de las contribuciones más influyentes a los estudios comparativos. El cuadro general de esta tipología tiene cuatro variantes: regímenes socialdemócratas, conservadores, del sur de Europa y liberales. Esta tipología se vuelve controvertida, particularmente cuando se consideran las desigualdades en la propiedad de la vivienda. Nuestro estudio tiene como objetivo evaluar la sostenibilidad de la tipología del régimen del Estado de bienestar con respecto a la reducción de las desigualdades en la propiedad de la vivienda. El documento utiliza datos del Estudio de Ingresos de Luxemburgo para analizar los cambios en las tasas de propiedad de vivienda para poblaciones de bajos ingresos en comparación con toda la población. Comparamos diez países que representan varios regímenes de bienestar desde 2000 hasta 2013/16 para examinar las variaciones de la propiedad de vivienda y las desigualdades sociales a lo largo del tiempo. Los resultados muestran que la distribución de países parece tener una correlación negativa entre los regímenes de bienestar (según el índice de Gini) y las tasas de propiedad de vivienda. En los países liberales (excepto Canadá) y los países del sur de Europa, las tasas de propiedad de vivienda cayeron con el tiempo. En la mayoría de estos países, las poblaciones de bajos ingresos experimentaron la mayor disminución en las tasas de propiedad de vivienda durante el período observado.

Palabras clave: Estado de bienestar, propiedad de vivienda, desigualdad social, vivienda, clase de bajos ingresos.

RESUM: La tipologia dels règims de l'Estat de benestar d'Esping-Andersen ha sigut una de les contribucions més influents als estudis comparatius. El quadre general d'aquesta tipologia té quatre variants: règims socialdemòcrates, conservadors, del sud d'Europa i liberals. Aquesta tipologia es torna contro- 
vertida, particularment quan es consideren les desigualtats en la propietat de l'habitatge. El nostre estudi té com a objectiu avaluar la sostenibilitat de la tipologia del règim de l'Estat de benestar respecte a la reducció de les desigualtats en la propietat de l'habitatge. El document utilitza dades de l'Estudi d'Ingressos de Luxemburg per a analitzar els canvis en les taxes de propietat d'habitatge per a poblacions de baixos ingressos en comparació amb tota la població. Comparem deu països que representen diversos règims de benestar des de 2000 fins a 2013/16 per a examinar les variacions de la propietat d'habitatge i les desigualtats socials al llarg del temps. Els resultats mostren que la distribució de països sembla tindre una correlació negativa entre els règims de benestar (segons l'índex de Gini) i les taxes de propietat d'habitatge. Als països liberals (excepte el Canadà) i els països del sud d'Europa, les taxes de propietat d'habitatge van caure amb el temps. En la majoria d'aquests països, les poblacions de baixos ingressos van experimentar la major disminució en les taxes de propietat d'habitatge durant el període observat.

Paraules Clau: Estat de benestar, propietat d'habitatge, desigualtat social, habitatge, classe de baixos ingressos.

\section{Introduction}

$\mathrm{T}$ The massive urban development in advanced capitalist countries is usually associated with social inequalities. In the fight against inequalities, the situation in these countries has become the subject of many recent debates. While some 'generous' countries are often ranked highly for their good general performances, they tend to fall down in terms of equality (Mavrozacharakis \& Tzagkarakis, 2018). Over the last three decades, the literature has shown that the inequality indicators in Scandinavian countries, for example, are significantly lower than elsewhere in advanced capitalist countries (Esping-Andersen, 2009; Wilkinson \& Pickett, 2011; Wulfgramm, Bieber, $\&$ Leibfried, 2017). However, many authors question the sustainability of this generous position in the context of new challenges brought by the recent economic crisis (Van den Berg, Plante, Raïq, Proulx, \& Faustmann, 2017). 
This crisis particularly affected the middle and low-income classes, which are now unable to generate sufficient income to access good housing services and solutions. This paper takes a closer look at the effect of welfare state regimes in combating social inequalities. How do rich democracies manage to reduce social inequalities between social classes in their access to homeownership? Is there any convergence between advanced capitalist countries (representing different welfare state regimes) in terms of homeownership? The hypothesis of a relationship between homeownership and welfare state regimes (or social inequalities) is quite complex. We know that many other factors (cultural background, financial and economic situation, demographic and geographic aspects, etc.) can deeply affect the level and the meaning of homeownership in different countries. For this reason we will explain the concept of homeownership in the context of the debates around social inequalities and welfare state regimes. We will also present a methodology to use the homeownership rate as an indicator to understand social inequalities and the differences between welfare state regimes.

\section{Social inequality and homeownership}

The forces of globalization and of economic union in Europe were expected to lead to convergence between countries in their struggle against inequalities. However, the current context is putting pressure on the standardization of social policies. Indeed, workers and companies tend to leave countries with high taxes, making the position of those offering social services and generous transfers untenable. The downward pressure on taxation leads to what is called a "race to the bottom" (Bernard \& Raïq, 2011; Brueckner, 2000), where all countries should adjust to the lowest common denominator of social generosity. This has become the subject of real social debate and political intervention in multidimensional aspects. In this context, and in terms of housing, citizens in many countries tend to agree that there is inequality between homeowners and renters (Mulder, 2004). Homeowners have greater control over their own housing situation. What they pay for their mortgage is accounted for as an investment and accumulation of wealth (Bernardi \& Poggio, 2004). According to some studies, homeowners pay less than renters in proportion to their income, and can afford a better quality home 
(Kurz \& Blossfeld, 2004). There is no agreement in the literature on an exact correlation between social class and homeownership. However, longitudinal studies show that the time required for the transition to homeownership is shorter for individuals in the upper social classes (Bernardi \& Poggio, 2004). The results of most studies concur in their perception that homeownership is associated with better social status. Several observers believe that governments must do better to facilitate homeownership for different social classes.

However, things are not so simple on the question of convergence, as shown by the persistent differences, even today, among the advanced capitalist countries. Governments often hold most of the power in the areas that can directly affect social inequality related to housing and homeownership. For more than four decades, some European countries have pursued policies that have led to a certain ideal of social justice, at least in terms of rhetoric and in many real measures such as income and financial support to reduce housing inequalities (Van den Berg et al., 2017). When generous governments confirm their commitment to a certain type of social policy, they become more likely to pursue the same perspective and tend to transform the political space (Huber $\&$ Stephens, 2001) and the general perception of homeownership. Countries may diverge from the notion that applying social justice and generosity to reduce housing inequalities necessarily involves increased homeownership. For example, Germany has one of the lowest homeownership rates in western Europe, but it has developed an effective subsidy program that has paved the way for a large private rental housing market (Voigtländer, 2009), thus supporting high quality social housing in this market. Private investors have closely collaborated in this strategy to limit housing inequalities. On the one hand, this generous rental housing program is more beneficial for low-income families as a targeted group; on the other hand, middle class families are more likely to make a transition to homeownership. Not all countries follow the same path as Germany. Many other (more liberal) governments adopt strategies that encourage homeownership (even for low-income groups) as a means to reduce social inequalities. These countries could have much higher homeownership rates. Countries with high homeownership rates appear to have the potential to reduce long-term poverty among retired people: as they will have already paid off their mortgages, pensioners will be in a better financial position at the end of their lives (Doling \& Ronald, 2010). 
This debate evidences the increasing interest in housing inequality to compare different social and economic entities. The homeownership rate itself is not enough to directly compare countries in terms of social inequality. However, to make this indicator more relevant, we will examine the variations in homeownership rates over time. If homeownership rates rise over time, this increases the evidence that social conditions have improved for new segments of the population. It is also important to find out how these variations may differ between low-income groups and the rest of the population. The paper also contributes to the debate by examining how social inequalities can vary in comparison with the variation of homeownership rates over time. By comparing these indicators over time, we will not confirm a direct relationship between social inequality and homeownership, but we can at least find out if the countries that manage to reduce social income inequality are also the ones that have seen an increase of homeownership rates.

\section{Welfare state regimes and the patterns of homeownership}

Esping-Andersen's original $(1990,1999)$ classification of welfare state regimes identified three ideal types: the 'liberal' regime characteristic of the Anglo-Saxon countries, the 'conservative' regimes found mainly on the European continent and the 'social democratic' regimes of the Nordic countries. After reviewing this typology, he added a fourth ideal type characterizing the southern European countries (Esping-Andersen, 1990, 2009). Many recent studies show that the regimes are and remain very different, especially with respect to social inequality outcomes (Van den Berg et al., 2017).

The 'social democratic' regimes aim to make standards of living as equal as possible through taxation, transfers and universal public services, even if their economy, like other countries, generates substantial differences in household incomes. Not only are their social policies among the most generous (though several of the major continental countries now rival or exceed them in overall social spending), but they have for many years adopted a coherent set of policies intended to facilitate the combination of various resources that enable people to have a good standard of living.

The 'liberal' regimes are the least generous of the four, with a strong emphasis on reliance on market income and only residual welfare state 
support for the very neediest. These regimes make little or no effort to help low-income workers or unemployed people. They favor the free play of the market and their efforts to reduce social inequality are minimal. Access to social programs is restrictive and increasingly takes the form of "workfare" (Dufour \& Boismenu, 2003; Varadya \& Matos, 2017).

'Conservative' welfare occupies an intermediate position. This regime has significant programs covering the traditional social risks such as housing, unemployment, aging and retirement, family, health, and so on (Stephens, 2016). These countries have quite generous housing assistance to support mostly lower income families with children. However, the southern European countries seem to take the same path as their neighbors but with lower social support.

Esping-Andersen's classification focuses on institutional contexts to compare welfare state regimes. This typology does not specify the relationship between homeownership and characteristics of the welfare state. In their comparative study, Kurz and Blossfeld (2004) revisited the typology more specifically with respect to homeownership. For these authors, in liberal regimes homeownership is clearly the favored form of housing. The private rental market is perceived as a transition for most people. At the same time, public housing for low-income groups is socially stigmatized. The main problem in liberal countries is the lack of income support and the job insecurity facing many people, which is the reason why many low-income families are challenged by the hurdle of the high initial cost of homeownership (Kemeny, 2001). In contrast, in social democratic regimes, where no stigma attaches to public housing, the public rental sector attracts a wide range of social classes (Kurz \& Blossfeld, 2004), and at the same time, homeownership is more accessible to all social classes because land prices and house prices tend to be highly regulated (Barlow \& Duncan, 1994). The conservative regime falls midway between the liberal and social democrat regimes: family policies (family income support) allow homeownership even for lowincome households. This regime also develops social programs even in the rental market in order to ensure a certain stability, which does not necessarily occur through homeownership (Kurz \& Blossfeld, 2004). In southern European regimes, public support to facilitate homeownership is low, and 
in many cases, people depend on family support to obtain the initial funds required to buy a house. Also, this regime is characterized by intergenerational solidarity, which means that young people stay longer in their parents' house (Arundel \& Ronald, 2015).

Given the differences in policy approaches among countries, one would expect housing inequality outcomes to vary considerably according to the characteristics of their welfare regimes. A priori, we would expect overall homeownership rates to vary according to the general variation of social inequality measured by the variation in the Gini index over time. In addition, we would expect that lower income households in 'liberal' jurisdictions would be considerably disadvantaged by the economic crisis, which affects the homeownership rate. The lower income households would fare better in the other jurisdictions (particularly social democratic and conservative regimes).

\section{Methods}

We use data from the Luxemburg Income Study (LIS), the current gold standard for international income comparisons, offering more than 200 demographic and income variables from over 40 countries (www.lisproject.org). We will compare countries twice, in 2007 and in 2013, years that coincide closely with the period of economic depression (the financial crash in 2007/8) in many countries, which affected the real estate market and access to homeownership. The data provides one variable that mainly distinguishes between owned and not owned living quarters. We recoded this variable to obtain the exact rate of owners (homeowners still repaying their mortgage and outright owners).

We used the Gini index to characterize overall social inequality and its evolution during this period. The Gini coefficient indicates the gap between an observed income distribution and a perfectly egalitarian income distribution. A Gini value of zero (0.0) corresponds to an egalitarian society, while a value of one (1.0) corresponds to a monopolization of the entire income by a single individual. As shown in many studies (Bernard \& Raïq, 2011), the value of the Gini coefficient is between (0.2) and (0.4) in western societies. We analyze whether the changes in social inequality affect access to homeownership. 
In our study, we examine the distribution of the countries' homeownership rate for low-income groups. Many authors (Misra \& Buding, 2007; Smeeding, 2006) define low-income populations as "households living below the $50 \%$ of the median income". When we explored this definition according to our data, we found that some countries have a very low rate of low-income households, which implies we would not have enough household cases to make significant comparisons for those countries. For our study, we therefore defined lowincome household using the lower quartile of income distribution. As recommended, we used the LIS equivalence scale to standardize for family size by dividing disposable income by the square root of family size. All results are weighted using the standardized norms of LIS.

In the comparative literature on welfare states (Esping-Andersen, 2009, 2017; Van den Berg et al., 2017), Anglo-Saxon countries are invariably treated as one homogeneous system, usually classified together as a 'liberal' or 'market-oriented' welfare state. For this study, we selected four liberal countries: United States, Canada, United Kingdom and Australia. We also selected two continental European countries that have sufficient similarities to represent the 'conservative' welfare regime: the Netherlands and Germany (Saint-Arnaud \& Bernard, 2003). For the southern European countries we selected Italy, Spain, and Greece. We compare all those regimes to Finland, which represents the Nordic social democratic countries (Saint-Arnaud \& Bernard, 2003). Unfortunately, the data is not available for some significant years in the other Nordic countries.

\section{Results}

Figure 1 shows the homeownership rates measured by the proportion of households living in their own house for the most recent years for which data are available. The southern European countries present the highest homeownership rates. Spain is at the top of the list with $76.7 \%$ of owners, followed by Greece and Italy with rates around 70\%. Two liberal countries (Canada and Australia) and Finland, representing a social democratic welfare regime, lie in the middle of the distribution with ownership rates between $65 \%$ and $68 \%$. A further two liberal countries (United States and UK) followed, with home- 


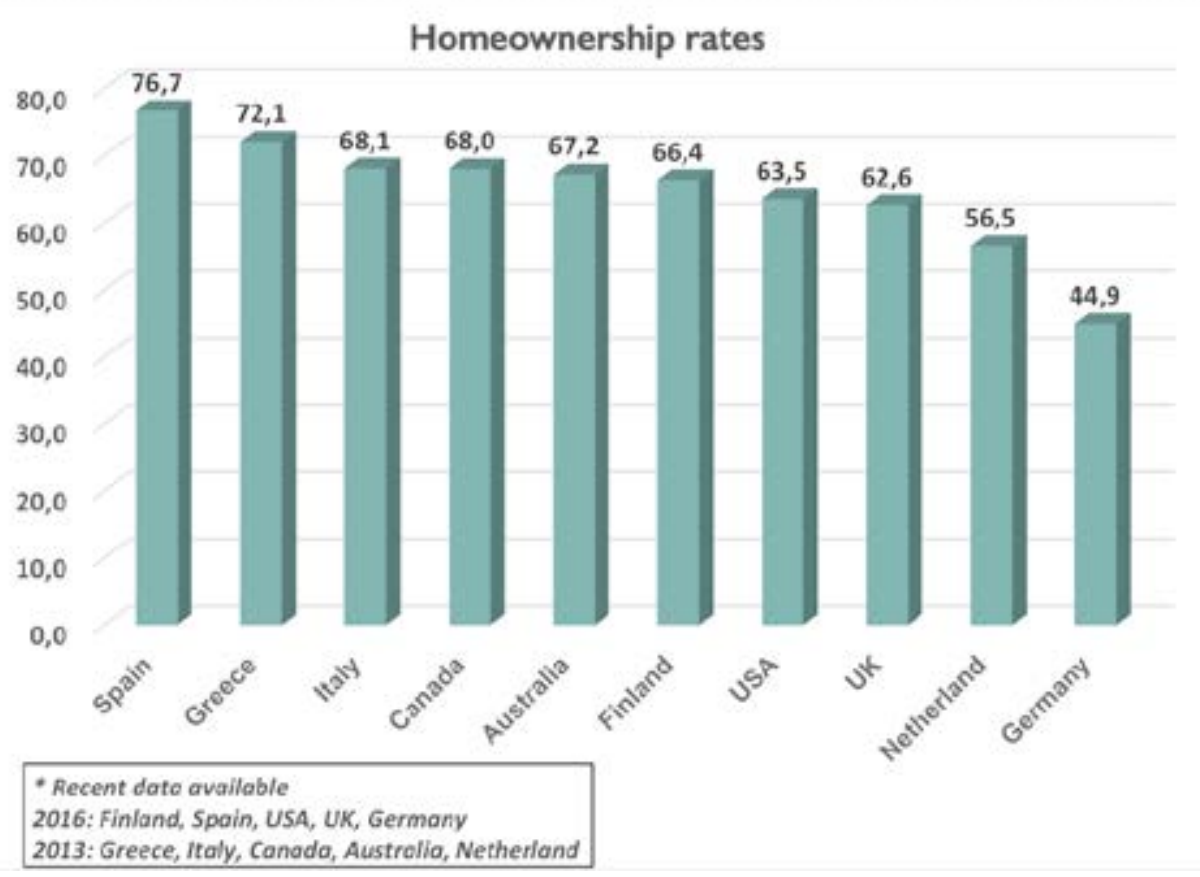

Figure 1. Homeownership rates.

Source: Data collected from the LIS mega data using the SAS program.

As expected, there are signs of homogeneity among certain countries, such as southern European societies that have the highest rates. As a social democratic country, Finland is somewhere in the middle and the conservative countries are together at the bottom. However, the position of 'liberal' countries appears less clear, but even so, all liberal countries tend to have a medium rate compared to other countries. Our results seem to suggest some overlap between the homeownership rates and the conception of welfare regimes. However, at this stage, we cannot associate the highest homeownership rates with a specific effect of welfare regime on social inequality. Even with low social inequality (measured by Gini index), some countries have a lower rate of homeownership, as displayed in Figure 2. 


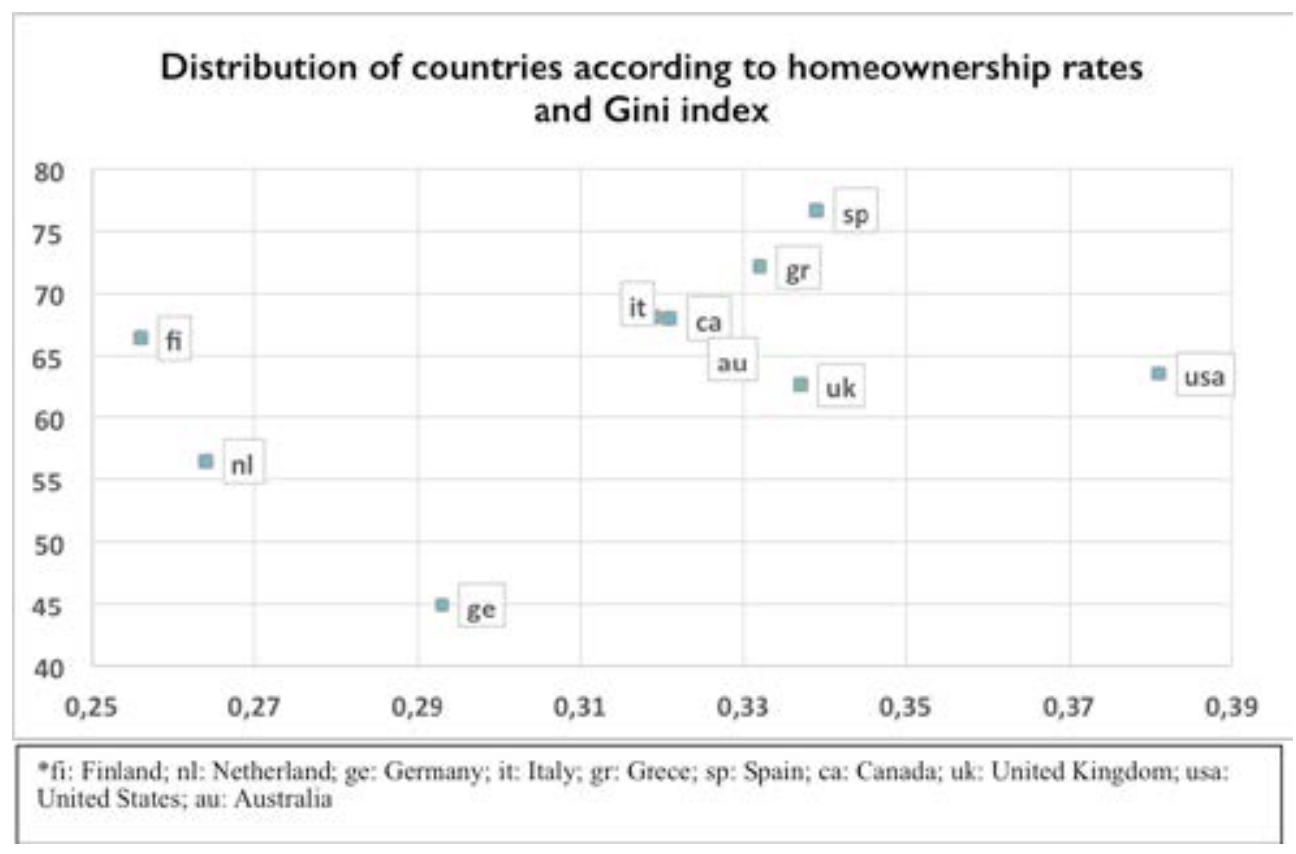

Figure 2. Distribution of countries according to homeownership rates and Gini index.

Source: Data collected from the LIS mega data using the SAS program.

We can identify some ideal types from the figure. The first (Finland and the Netherlands) presents low social inequality and a medium homeownership rate. The second type contains the southern European countries and the liberal countries (excluding the United States). In this group, the Gini index is high and homeownership is medium to high. Germany and the United States are both outliers but with some differences. On the one hand, Germany has a low Gini index (which means low social inequality) but a very low homeownership rate. On the other hand, the United States has a very high social inequality index and a medium homeownership rate. The distribution of countries seems to show a negative correlation between welfare regimes and homeownership rates.

Regarding the variation in the homeownership rate, conservative and social democratic regimes performed better than other countries, as can be seen from Figure 3. Between 2000 and 2013/16, the homeownership rate increased in Germany, the Netherlands, and Finland. This suggests that many new families had the chance to become owners in those countries. In the other regimes (liberal and southern European countries), the homeownership 
rate fell (a decline of more than $12 \%$ in Greece). In those countries, households seem to be severely affected by the economic crisis. However, note that Canada in particular performed relatively well in increasing the homeownership rate during the period analyzed.

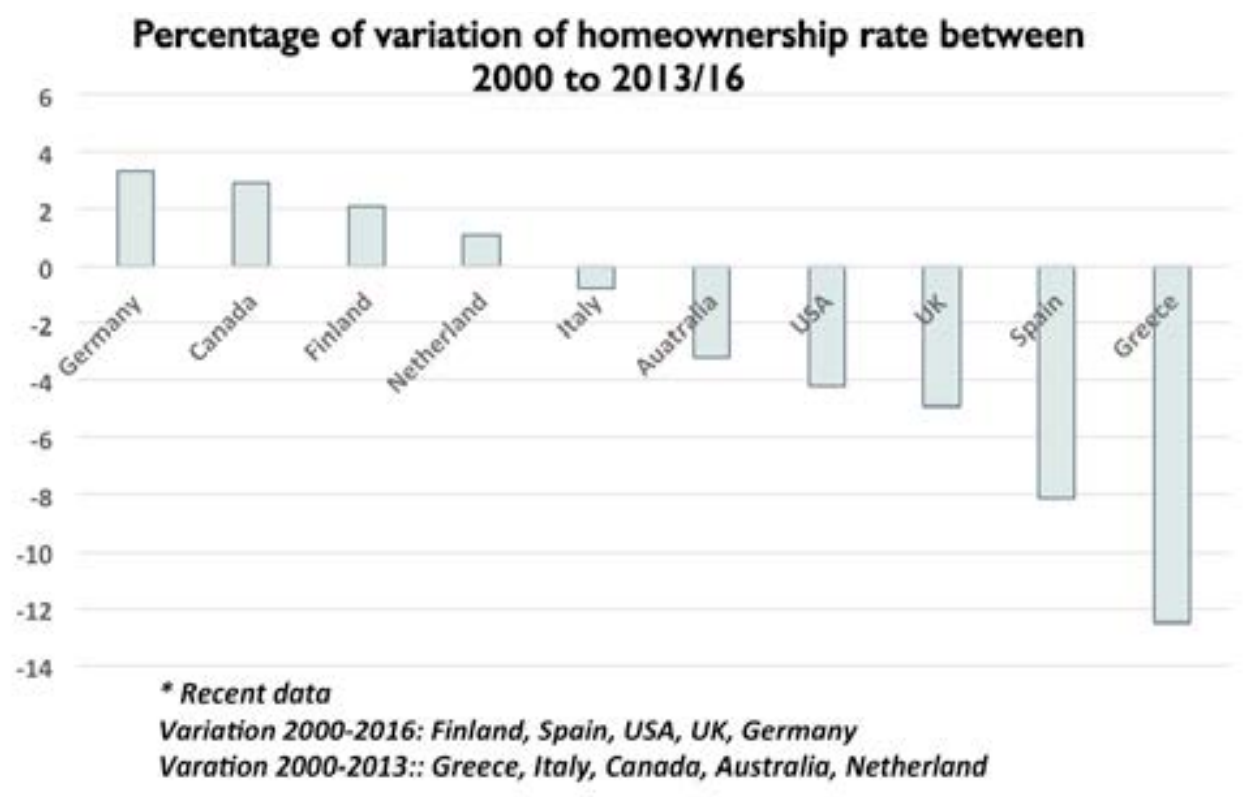

Figure 3. Percentage of variation of homeownership rate between 2000 to 2013/16.

Source: Data collected from the LIS mega data using the SAS program.

Turning to the homeownership rate for households in the lowest income quartile (Figure 4), the trend seems to be quite similar to that of the entire population. The rate is higher in the southern European countries and lower in the continental European countries. Finland and the liberal countries present medium rates. For all the selected countries, low-income households are less likely to be owners than the rest of the population. However, the gap between the total population and the lowest quartile is very high in Canada, the United States and the Netherlands. The southern European countries present the lowest gap, together with Australia. 


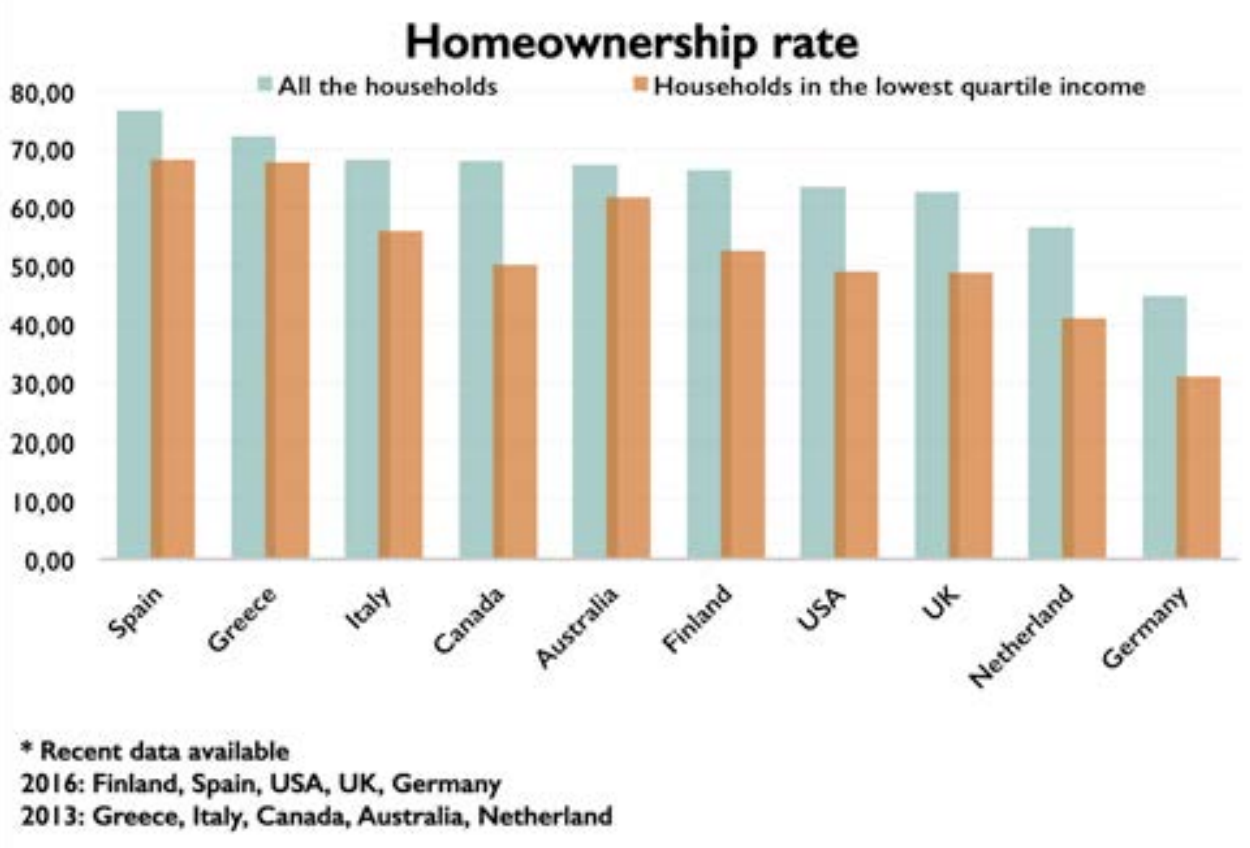

Figure 4. Homeownership rate. Source: Data collected from the LIS mega data using the SAS program.

The remaining question is to find out if the households in the lowest quartile income experienced the same trend between 2000 (before the economic crisis) and 2013/16 as compared to the entire population. As we can see in Figure 5, the line 0 indicates 'no variation' (in terms of access to homeownership between 2000 and 2013/16). Above the line indicates an increase in the homeownership rate. Below the line indicates a decrease in the homeownership rate during the same period.

The Netherlands shows the best performance because the lowest quartile of income corresponds to the highest increase (the orange area) in terms of homeownership rates. In this country, more low-income households became homeowners during the observed period. Even for the entire population, the homeownership rate increased in the Netherlands but still less than for lower income households. In Germany also, both categories (low-income households and the entire population) show a positive increase but the households in the lower quartile income are slightly disadvantaged (lower increase of homeownership rate), compared to the entire population. Canada and Finland share some similarities, with an increase in homeownership rate for the entire 
population (in blue above the line 0 ) and a small decrease for the low-income households (in orange below the line 0 ). In the other countries, both lowincome households and the entire population present a decrease in the homeownership rate. In Italy and the United States, the households in the lowest income quartile were more disadvantaged. The situation was very intense for Greece and Spain where the homeownership rate fell by more than $15 \%$ in the lower quartile.

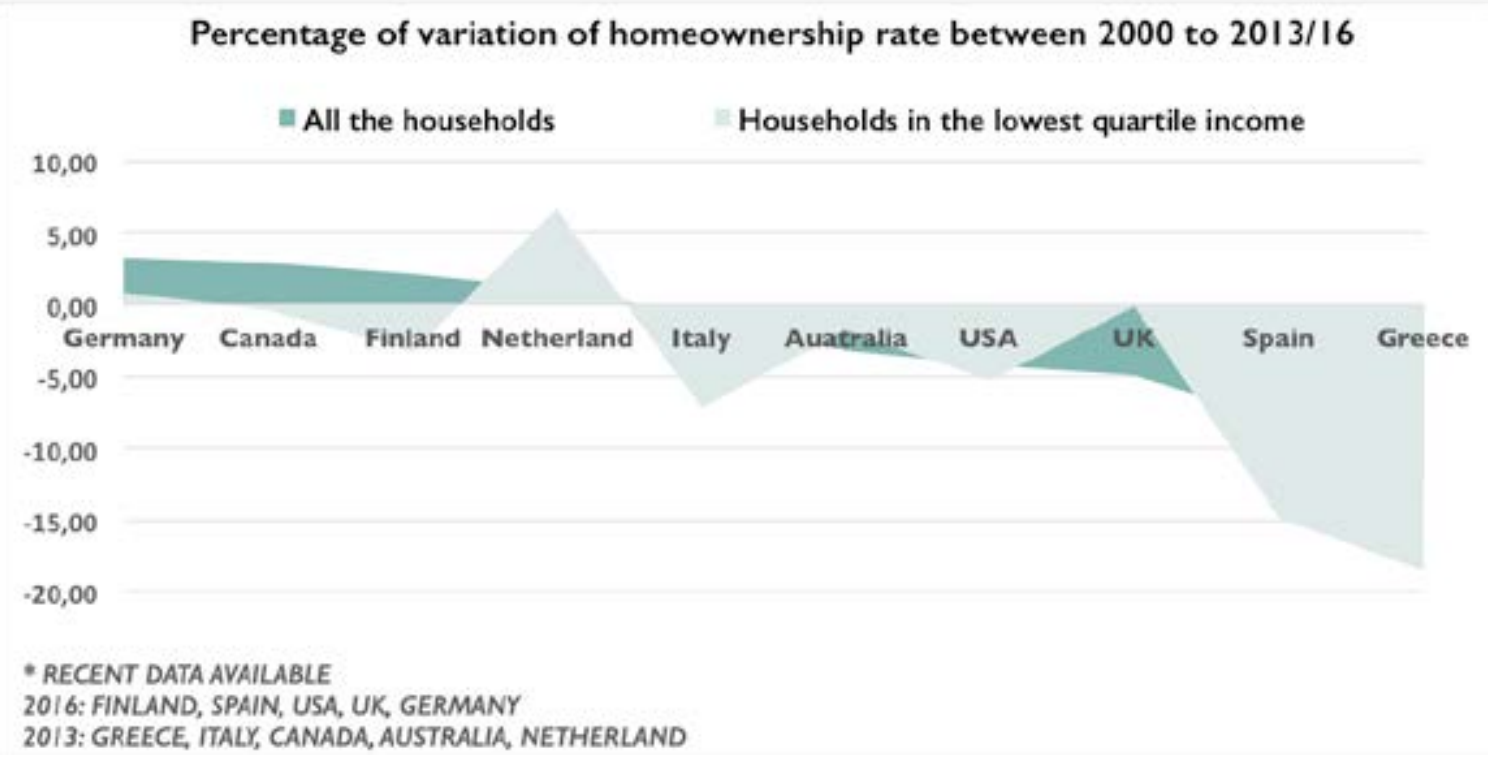

Figure 5. Percentage of variation of homeownership rate between 2000 to 2013/16.

Source: Data collected from the LIS mega data using the SAS program.

\section{Discussion}

Can we confirm the original typology of Esping-Andersen from our analysis of social inequality through homeownership rates? The homeownership rate is a result of the complex interplay of government policies, economic situation, innovations in mortgage markets, and demographic and cultural factors that are largely beyond government control. A higher homeownership rate does not mean specific welfare regimes perform better in reducing social inequality. Our results show that southern European countries share some sim- 
ilarities, as all of them present medium to high homeownership rates. The conception of the family and housing behavior or intergenerational housing in those countries generate higher ownership rates, since most young people stay longer in their parents' home (Arundel \& Ronald, 2015; Varadya \& Matos, 2017). In southern European countries, significant numbers of public housing units were sold to sitting tenants, which explains the higher homeownership rate (Dewilde \& De Decker, 2015)Theory and Society $</$ secondary-title $><$ / titles $><$ periodical $><$ full-title $>$ Housing, Theory and Society $</$ full-title $></$ periodical $><$ pages $>121-161<$ pages $><$ volume $>33<$ /volume $><$ number $>2<1$ number $><$ section $>121<$ /section $><$ dates $><$ year $>2015</$ year $></$ dates $><$ isbn $>$ 1403-6096\&\#xD;1651-2278 $<$ /isbn $><$ urls $></$ urls $><$ electronic-resour ce-num $>10.1080 / 14036096.2015 .1109545</$ electronic-resource-num $></$ record $></$ Cite $></$ EndNote $>$. However, for this regime, there is no active support to reduce social inequality.

The medium homeownership rate in Finland (an example of the generous social democratic regime) and for the conservative regime (represented by Germany and the Netherlands) does not necessarily imply a lack of government support. These households have many other alternative ways of accessing decent housing without owning their own property. In these countries, families can benefit from allowances that help (directly or through income tax) to reduce the cost of rental in the real estate market even during the period of retrenchment policies (Ruonavaara, 2012). Liberal countries have medium (or even high) homeownership rates but also higher social inequality as measured by the Gini index. We find various policies behind this similar outcome in liberal countries, but their main priority is to reduce public intervention. The existing housing policies are poorly implemented (Silverman, 2011). According to Kurz and Blossfeld (2004), in liberal countries, where a "privatist" ideology prevails, homeownership rates should be higher and public spending on housing lower than they are in conservative and social democratic countries, where a "collectivist" ideology is dominant. These authors hold that there is a negative correlation between social expenditure (including social housing support) and homeownership rates. They explain that the curve of the homeownership rate is due to the lifetime costs of home ownership. When homes are owned (as opposed to rented), the lifetime costs of housing are typically skewed: initially costs are high and they fall 
slowly overtime, becoming very low in old age (Kurz \& Blossfeld, 2004). This is probably the reason why our results show that in liberal and southern European countries (known for their high social inequality due to low social expenditure and low housing support), people are more likely to own their homes (in comparison with a conservative regime). When social inequality is high, homeownership will compensate for smaller pensions in old age.

To understand the effectiveness of welfare state regimes in maintaining their homeownership levels during the last two decades, we examined changes in the homeownership rates between 2000 and 2013/16. Our results show clearly that most of the liberal countries and southern European countries have seen a decline in the homeownership rate for both lower income households and the entire population. One of the main explanations suggested is the lack of support for precarious groups affected by the economic crisis (Fitzpatrick \& Watts, 2018). Of course, many other factors (cultural background, financial and economic situation, real estate market, innovation in mortgage, demographic and geographic aspects, etc.) can play an important role in the variations. However, welfare state regimes can be seen as a context in which different pillars come together to maintain a certain level of equality. When a country loses more than $15 \%$ of its homeowners in less than 20 years, this indicates a problem of social inequality since a large part of the population is no longer able to invest through homeownership. The situation in southern European countries has also been considerably affected by the economic crisis. Unemployment rates in this region are the highest among the countries compared in this study, according to OECD data. In Greece, the unemployment rate increased from $11 \%$ in the early 2000 s to $24 \%$ in 2016 . In Spain, the unemployment rate was $26 \%$ in 2013 (compared to $14 \%$ in 2000). In Italy, where the situation was less severe, the unemployment rate reached $12 \%$ in 2013 . In all the other selected countries in this study, despite small fluctuations, the unemployment rate never exceeded $9 \%$ (between $4.1 \%$ in Germany and 8.8\% in Finland in 2016)

Conservatives and social democratic regimes maintained a low level in the Gini index. In these countries, housing policies, as well as other social policies, have aimed to establish a system that provides a lower rental market which enables the target groups to have sustainable housing (Kurz 
\& Blossfeld, 2004). At the same time, there are more opportunities for every social class to transition to homeownership. We can see through these countries how successful housing policy can provide long-term solutions for households that have limited financial resources. Canada, as a liberal country, shows better results than the other Anglo-Saxon jurisdictions. This is what is known as Canada's exceptionalism (Van den Beg et al., 2017): Canada's experience seems to be different, as there are disparities between its provinces. In jurisdictions where social inequality is lower (such as Quebec), the homeownership rate tends to be lower than the national average, but this rate will be more likely to remain stable or increase (Van den Berg et al., 2017). However, Canada' universal health care coverage, the generous support for families with children, and employment and income support all played an important role in protecting households and promoting a massive growth of mortgage securitization (Walks, 2014,). Canada saw an increase in its homeownership rate for the entire population and almost no change for the lowincome households.

Examining the housing issue means focusing on one of the major social issues of modern societies and urban development. The fact that both individuals and communities are implicated raises interest in the debate (Dawkins, 2017; Hoffman, 2012). Housing inequality is one of the social inequalities that reflect both social stratification and the dissimilarity of opportunity in many areas (Maclennan \& Miao, 2017)2017. Even if our results have confirmed the similarities within certain welfare regimes, there is evidence for differences in terms of how countries are capable of reducing social inequalities through homeownership. Within the same regimes and facing the same pressure of globalization, countries still have their own margin to maneuver in dealing with housing inequalities and how to help their low-income populations. Germany, the Netherlands and even Canada can do better than the Finnish "gold medalist" in increasing their homeownership rates, although in Canada (as a liberal regime), the Gini index is much higher. The homeownership race may not necessarily be the big challenge. Sometimes it is better to be a tenant with a good standard of living than a homeowner in a country with high social inequalities. More advanced qualitative studies are needed to explore countries' strategies and rational choices between the rental market and homeownership. 


\section{References}

Arundel, R., \& Ronald, R. (2015). Parental co-residence, shared living and emerging adulthood in Europe: semi-dependent housing across welfare regime and housing system contexts. Journal of Youth Studies. doi:10.1080/13676261.2015.1112884

Barlow, J., \& Duncan, S. (1994). Success and fail ure in housing provision. European systems compared: Oxford: Pergamon Press.

Bernard, P., \& RaïQ, H. (2011). Le Québec est-il une société égalitaire: Institut du nouveau monde (Boréal).

Bernardi, F., \& Poggio, T. (2004). Home Ownership and Social Inequality in Italy. In K. Kurz \& H.-P. Blossfeld (Eds.), Home Ownership and Social Inequality in Comparative Perspective: Stanford University Press.

Brueckner, J. K. (2000). Welfare Reform and the Race to the Bottom: Theory and Evidence. Southern Economic Journal, 66(3).

Dawkins, C. J. (2017). Autonomy and Housing Policy. Housing, Theory and Society, 34(4), 420-438.

Dewilde, C., \& De Decker, P. (2015). Changing Inequalities in Housing Outcomes across Western Europe. Housing, Theory and Society, 33(2), 121-161. doi:10.1080/14036096.2015.1109545

Doling, J., \& Ronald, R. (2010). Home ownership and asset-based welfare. Journal of Housing and the Built Environment, 25(2), 165-173. doi:10.1007/s10901-009-9177-6

Dufour, P., \& Boismenu, G. (2003). L'aide au conditionnel. La contrepartie dans les mesures envers les personnes sans emploi en Europe et en Amérique du Nord. Presse de l'université de Montréal.

ESPING-ANDERSEN, G. (1990). The three worlds of welfare capitalism. New Jersey.

Esping-Andersen, G. (2009). The Incomplete Revolution: Adapting to Women's New Roles. Cambridge: Polity Press.

Esping-Andersen, G. (2017). Politics against Markets: The Social Democratic Road to Power.

FitzPatrick, S., \& Watts, B. (2018). Final findings: Social Housing (fixed-term tenancies). Welfare Conditionality: Sanctions, Support and Behaviour. York: University of York.

Hoffman, A. v. (2012). History lessons for today's housing policy: the politics of low-income housing. Housing Policy Debate, 22(3), 321-376. 
Huber, E., \& Stephens, J. D. (2001). Developments and Crisis of the Welfare State: Parties and Policies in Global Markets: The University of Chicago Press.

Kemeny, J. (2001). Comparative housing and welfare: Theorising the relationship. Journal ofHousing and the Built Environment, 16, 53-70.

Kurz, K., \& Blossfeld, H.-P. (2004). Home Ownership and Social Inequality in Comparative Perspective: Stanford University Press.

Maclennan, D., \& Miao, J. (2017). Capital, Housing And Inequality In The 21st Century. Housing, Theory and Society, 34(2), 127-145.

Mavrozacharakis, E., \& Tzagkarakis, S. I. (2018). Modern Welfare State and Social Democracy: Interdependence and Policy Importance. Open Access Library Journal, 5(e4406).

Misra, J., \& Buding, M. (2007). Reconciliation policies and the effects of motherhood on employment, earning and poverty. Journal of Comparative Policy Analysis, 9(2), 135-155.

Mulder, C. H. (2004). Home Ownership and Social Inequality in the Netherlands In K. Kurz \& H.-P. Blossfeld (Eds.), Home Ownership and Social Inequality in Comparative Perspective: Stanford University Press.

RuonavaARA, H. (2012). Home ownership and Nordic housing policies in 'retrenchment'. In R. Ronald \& M. Elsinga (Eds.), Beyond Home Ownership Housing, Welfare and Society.

Saint-Arnaud, S., \& Bernard, P. (2003). Convergence or Resilience? A Hierarchical Cluster Analysis of the Welfare Regimes in Advanced Countries. Current Sociology, 51(5), 499-527.

Silverman, R. M. (2011). The Four Horsemen of the Fair Housing Apocalypse: A Critique of Fair Housing Policy in the USA. Critical Sociology, 38(1), $123-140$.

Smeeding, T. M. (2006). Poor People in Rich Nations: The United States in Comparative Perspective. Journal of Economic Perspectives, 20(1).

STEPhens, M. (2016). Using Esping-Andersen and Kemeny's Welfare and Housing Regimes in Comparative Housing Research. Critical Housing Analysis, 3(1), 19-29.

Van den Berg, A., Plante, C., RaïQ, H., Proulx, C., \& Faustmann, S. (2017). Combating Poverty: Quebec's Pursuit of a Distinctive Welfare State: University of Toronto Press.

Varadya, D. P., \& Matos, F. (2017). Comparing public housing revitalization in a liberal and a Mediterranean society (US vs. Portugal). Cities, 64(April), 37-46. 
Voigtländer, M. (2009). Why is the German Homeownership Rate so Low? Housing Studies, 24(3), 355-372. doi:10.1080/02673030902875011

W ALKs, A. (2014,). Canada's Housing Bubble Story: Mortgage Securitization, the State, and the Global Financial Crisis. International Journal of Urban and Regional Research, 38(1), 256-284.

Wilkinson, R., \& Pickett, K. (2011). The Spirit Level: Why Greater Equality Makes Societies Stronger: Bloomsbury Publishing; Reprint edition.

Wulfgramm, M., Bieber, T., \& Leibfried, S. (2017). Welfare State Transformation and Inequality in OECD Countries. Palgrave Macmillan, London. 